\title{
Pengolahan Air Terproduksi dengan Membran Bioreaktor di Wilayah Penambangan Wonocolo
}

\author{
Wibiana Wulan Nandari ${ }^{\mathrm{a}^{*}}$, Ekha Yogafanny ${ }^{\mathrm{b}}$, Ekha Yogafanny $^{\mathrm{b}}$ and M. Th. Kristiati ${ }^{\mathrm{c}}$ \\ ${ }^{a}$ Chemical Engineering Department Universitas Pembangunan Nasional "Veteran" Yogyakarta, Jl. SWK 104 Condongcatur \\ Yogyakarta 55283, Indonesia \\ ${ }^{b}$ Environmental Engineering Department Universitas Pembangunan Nasional “Veteran” Yogyakarta, Jl. SWK 104 \\ Condongcatur Yogyakarta 55283, Indonesia \\ 'Petroleum Engineering Department Universitas Pembangunan Nasional "Veteran” Yogyakarta, Jl. SWK 104 Condongcatur \\ Yogyakarta 55283, Indonesia
}

\section{Artikel histori : \\ Diterima 29 Juli 2018 \\ Diterima dalam revisi 15 Agustus 2018 \\ Diterima 31 September 2018 \\ Online 31 Oktober 2018}

\begin{abstract}
ABSTRAK: Masalah pengolahan air terproduksi di wilayah penambangan Wonocolo mulai menjadi perhatian sejak ditetapkannya Wonocolo sebagai Petroleum Geoheritage. Air terproduksi yang ikut terangkut ke permukaan pada saat pengambilan minyak bumi di sumur minyak Wonocolo memiliki tingkat kekeruhan 105 NTU, Total Dissolved Solids (TDS) 1714 mg/L, Total Suspended Solids (TSS) $90 \mathrm{mg} / \mathrm{L}$, dan nilai COD 77,9 mg/L. Tujuan dari penelitian ini adalah untuk mengetahui pengaruh media filtrasi pasir aktif dan karbon aktif sebelum air dimasukkan ke membran bioreaktor. Hasil pengolahan air terproduksi tanpa menggunakan media filtrasi menghasilkan air dengan tingkat kekeruhan 0,33 NTU, COD 35, TSS 8 mg/L dan efisiensi penurunan TDS 90,45 \%, sedangkan dengan pasir aktif menghasilkan tingkat kekeruhan 0 NTU, COD 7,1 mg/L; TSS 6 mg/L, dengan efektivitas penurunan TDS 91,85\%. Sementara pada media karbon aktif, tingkat kekeruhan 0,27 NTU; COD 10,5 mg/L; TSS 4 $\mathrm{mg} / \mathrm{L}$ dengan efektivitas penurunan TDS 90,97\%. Pengolahan menggunakan media filtrasi menghasilkan air yang memiliki kualitas lebih baik dari pada tanpa filtrasi. Media filtrasi pasir aktif lebih baik daripada karbon aktif. Media filtrasi juga dapat menurunkan beban membran dalam mengolah air.
\end{abstract}

Kata Kunci: Air terproduksi; Membran bioreaktor; pasir aktif; karbon aktif

ABSTRACT: The issues of produced water has become very much considered since the stipulation of "Wonocolo" as Petroleum Geoheritage. Produced water transported to the surface during oil extraction at the Wonocolo oil well has a turbidity level of 105 NTU, Total Dissolved Solids (TDS) of $1714 \mathrm{mg} / \mathrm{L}$, Total Suspended Solids (TSS) of $90 \mathrm{mg} / \mathrm{L}$, and COD value of $77.9 \mathrm{mg} / \mathrm{L}$. The purpose of this study was to determine the effect of filtration media (active sand and activated carbon) before water was put into the bioreactor membrane. The results of water treatment without using filtration media produced water with turbidity levels of $0.33 \mathrm{NTU}$, COD $35 \mathrm{mg} / \mathrm{L}$, TSS $8 \mathrm{mg} \mathrm{L}$ and efficiency of TDS reduction of $90.45 \%$ while using active sand produced water with turbidity levels of 0 NTU, COD $7.1 \mathrm{mg} / \mathrm{L}$, TSS $6 \mathrm{mg} \mathrm{L}$ and efficiency of TDS reduction of $91.85 \%$. For activated carbon, turbidity level was 0.27 NTU, COD $10.5 \mathrm{mg} / \mathrm{L}$, TSS $4 \mathrm{mg}$ L and efficiency of TDS reduction of $90.97 \%$. From the results of the analysis, processing using filtration media produces water that has better quality and active sand filtration media better than activated carbon.

Keywords: Produced water; Membrane bioreactor; active sand; activated carbon

\section{Pendahuluan}

Saat ini masih banyak penambangan minyak yang dilakukan secara tradisional, salah satunya yaitu penambangan di wilayah Sumur Tua Wonocolo. Pada saat pengambilan minyak bumi di sumur minyak tua Wonocolo, terdapat zat cair yang terangkat ke permukaan yang $90 \%$ zat cair tersebut adalah air terproduksi.
Penambangan tradisional ini tidak diiringi dengan pengolahan air terptoduksi sehingga air terproduksi yang dihasilkan mengandung partikel padatan yang terlarut dan tersuspensi, minyak, fenol, COD, BOD, dan logam berat yang pada hasil uji lab belum aman untuk dibuang ke badan sungai. Dengan ditetapkannya sumur minyak tua Wonocolo sebagai Petroleum Geoheritage, maka penelitian untuk mengolah limbah berupa air terproduksi perlu dilakukan. Penelitian ini mendukung pengelolaan

*Corresponding Author:

Email: wibianawulan@upnyk.ac.id 
Petroleum Geoheritage Wonocolo sebagai potensi wisata yang menunjang ciri khas lapangan minyak bumi sehingga masyarakat dapat memiliki pandangan bahwa penambangan minyak juga memperhatikan aspek lingkungan karena limbah yang dihasilkan layak untuk dibuang dan tidak mencemari lingkungan.

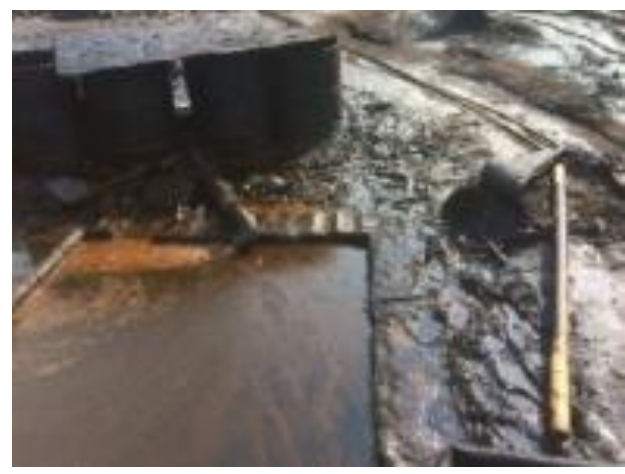

Gambar 1.Penampungan Air Terproduksi dan Minyak

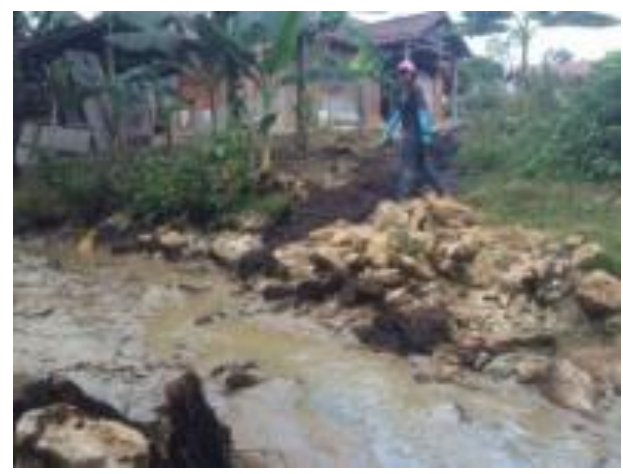

Gambar 2. Pembuangan Air Terproduksi ke Sungai

Teknologi pengolahan air terproduksi yang sedang berkembang saat ini adalah teknologi membran. Sebelumnya membran digunakan sebagai salah satu unit proses pada tertiary treatment, namun saat ini mulai dikembangkan teknologi membran sebagai aplikasi tunggal atau terkombinasi (Ivory, D., 2015). I.G. Wenten (2014) mengatakan bahwa kehadiran teknologi membran sebagai proses pemisahan memberikan alternatif baru untuk meningkatkan kinerja pengolahan limbah konvensional. Kombinasi membran dengan proses lumpur aktif akan memunculkan sistem pengolahan limbah cair yang disebut bioreaktor membran. Ada tiga jenis bioreaktor membran, yaitu bioreaktor pemisahan biomassa, bioreaktor membran aerasi, dan bioreaktor membran ekstraktif. Membran bioreaktor adalah proses pengolahan yang mengintegrasikan membran semipermeable dengan proses biologis (Judd, 2011).

Proses membran mikrofiltrasi, ultrafiltrasi, dan nanofiltrasi merupakan proses membran yang paling sering digunakan untuk bioreaktor membran. Dalam peranannya sebagai proses pemisahan, membran berfungsi sebagai penghalang yang selektif di antara dua fasa yang me- mungkinkan lewatnya komponen tertentu, namun menahan komponen lainnya. Proses membran bekerja berdasarkan perbedaan tekanan sebagai gaya dorong (Wenten, 2014).

Mulder (1996) mengelompokkan membran berdasarkan gradien tekanan gaya dorong dan permeabilitasnya, yaitu:

a. Mikrofiltrasi (MF), membran jenis ini beroperasi pada tekanan berkisar $0,1 \quad-2$ bar dan batasan permeabilitasnya lebih besar dari $50 \mathrm{~L} / \mathrm{m}^{2}$,jam.bar

b. Ultrafiltrasi (UF), membran jenis ini beroperasi pada tekanan antara $1-5$ bar dan batasan permeabilitasnya adalah $10-50 \mathrm{~L} / \mathrm{m}^{2}$,jam.bar

c. Nanofiltrasi, membran jenis ini beroperasi pada tekanan antara 5 - 20 bar dan batasan permeabilitasnya adalah $1,4-12 \mathrm{~L} / \mathrm{m}^{2}$,jam.bar

d. Reverse Osmosis (RO), membran jenis ini beroperasi pada tekanan antara $10-100$ bar dan batasan permeabilitasnya adalah $0,05-1,4 \mathrm{~L} / \mathrm{m}^{2}$,jam.bar.

Air terproduksi mengandung logam-logam dalam konsentrasi tinggi, material terlarut organik yang volatil, bahan toksik yang terikut dengan produk hidrokarbon, dan padatan terlarut dalam level tinggi. Komponen-komponen tersebut harus dihilangkan sebelum air terproduksi dibuang atau kembali pada operasi pengeboran. Teknologi pemisahan konvensional dengan cara gravitasi kurang efektif. Adapun keuntungan penggunaan Reverse Osmosis untuk pengolahan air terproduksi adalah efektif menghilangkan partikel, minyak terdispersi, dan minyak teremulsi; ukuran lebih kecil; energi lebih rendah; laju lebih besar (Wenten, 2014).
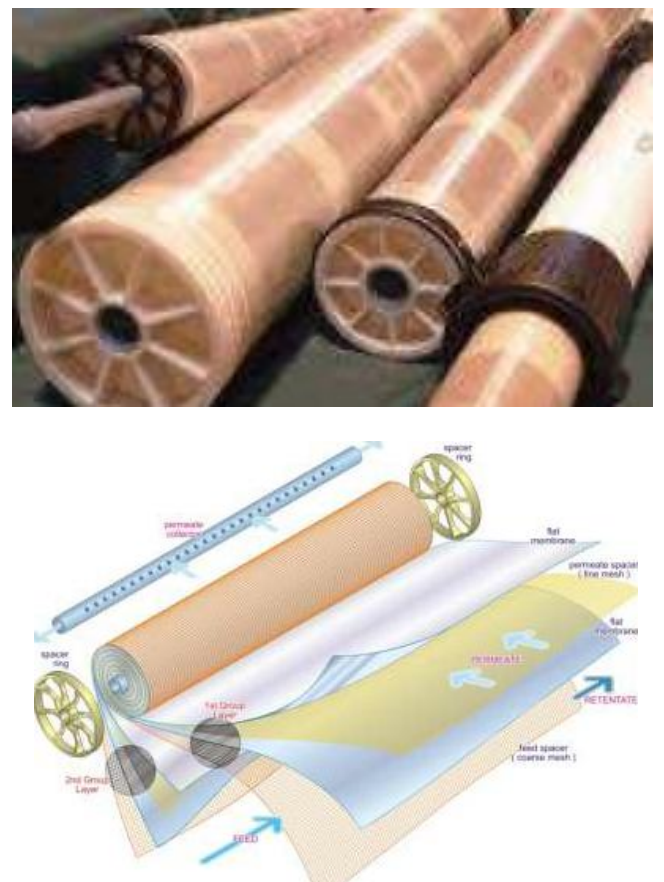

Gambar 3. Membran berbentuk spiral (Wenten, 2014)

Pada penelitian ini, air terproduksi diolah menggunakan membran bioreaktor reverse osmosis yang berbentuk spiral dengan enam gulungan dan kapasitas 100 
gallon per day (GPD) dengan pre-treatment sebelum membran adalah pengolahan air denan cara konvensional yang meliputi sedimentasi, koagulasi, floatasi, aerasi, dan filtrasi menggunakan media pasir aktif dan karbon aktif.

\section{Metode Penelitian}

Penelitian ini menggunakan membran bioreaktor sebagai aplikasi terkombinasi dengan beberapa unit konvensional sebagai pretreatment sebelum masuk ke dalam membran. Sehingga tahapan penelitian ini dibagi menjadi dua, yaitu:

- Tahap pre-treatment, yang meliputi proses sedimentasi, koagulasi aerasi, dan filtrasi.

- Menggunakan membran bioreaktor

Pada tahap filtrasi menggunakan membran, air terproduksi diolah dengan tiga macam perlakuan, yaitu :

- Air terproduksi langsung dari proses aerasi dilewatkan membran

- Air terproduksi dilewatkan media filtrasi pasir aktif kemudian dimasukkan ke dalam membran

- Air terproduksi dilewatkan media filtrasi karbon aktif kemudian dimasukkan ke dalam membran.
Analisa hasil dilakukan setiap kali proses, baik input maupun output sehingga diketahui pengaruh perlakuan terhadap hasil analisa air terproduksi.

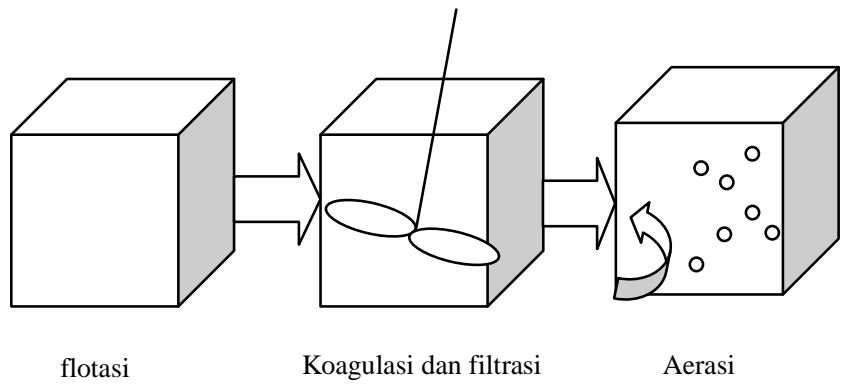

Gambar 4. Unit Konvensional untuk Pre-treatment Air terproduksi

Membran yang dipakai dalam penelitian ini berjenis membran reverse osmosis diperoleh dari INVIRO dengan kapasitas 100 gallon per day (GPD), berbentuk spiral dengan enam gulungan.

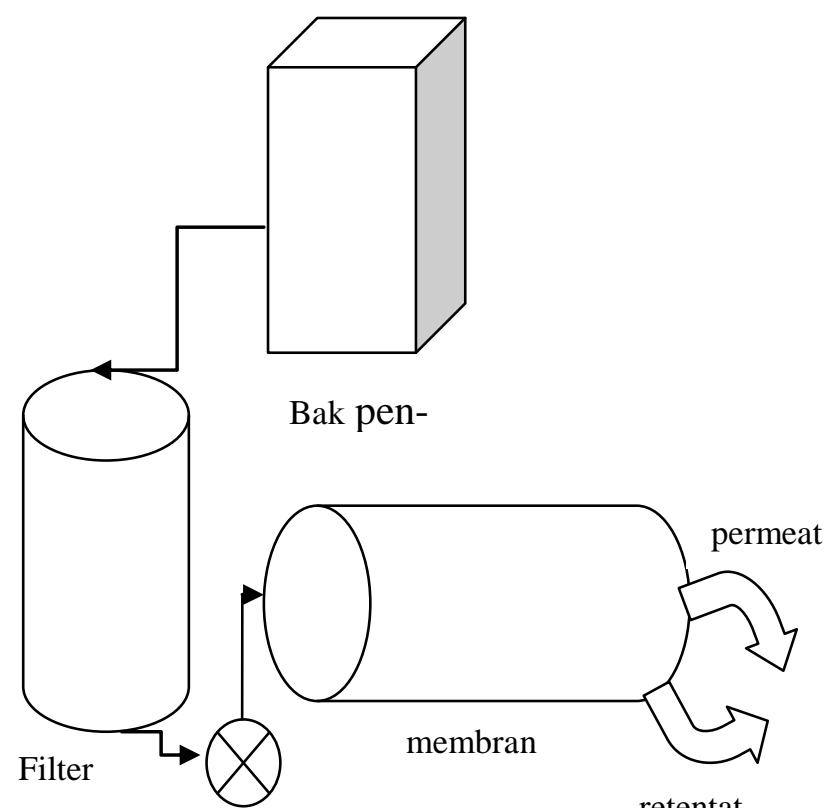

pompa

Gambar 5. Proses Filtrasi menggunakan Membran Bioreaktor

\section{Hasil dan Pembahasan}

\subsection{Kualitas Air terproduksi di wilayah Pertambangan Wonocolo}

Dalam penentuan tingkat pencemaran, metode perhitungan yang digunakan adalah indeks pencemaran, dengan parameter uji kualitas air adalah Total Dissolved Solid
(TDS), Total Suspended Solid (TSS), Chemical Oxygen Demand (COD), Biological Oxygen Demand (BOD) dan Minyak Lemak. Dari hasil analisa laboratorium, tingkat kekeruhan air terproduksi yang diambil dari wilayah penambangan Wonocolo memiliki tingkat kekeruhan 105 NTU dan TDS $2493 \mathrm{mg} / \mathrm{L}$. Air limpahan tersebut merupakan satu-satunya sumber air yang masuk ke sungai 
dan akan terus bertambah tingkat pencemarannya jika air terproduksi tidak diolah terlebih dahulu.

Sebelum air dilewatkan membran bioreaktor, air tersebut diolah dengan cara konvensional, yaitu dengan melalui proses floatasi (memisahkan partikel padat dari fase cair), koagulasi (ditambahkan tawas sebagai bahan penggumpal sambil diaduk dan diendapkan), aerasi, dan melewati media filtrasi.

Saat melewati proses floatasi, kekeruhan air terproduksi berkurang dari 105 NTU menjadi 26,28 NTU dan namun TDS tidak berkurang banyak yaitu dari $2493 \mathrm{mg} / \mathrm{L}$ menjadi $2471,33 \mathrm{mg} / \mathrm{L}$. Koagulasi menggunakan tawas untuk menggumpalkan partikel-partikel yang berukuran kecil sehingga bisa mengendap. Proses koagulasi mampu menurunkan turbiditas hingga 15,21 NTU namun TDS naik menjadi 2546,67 mg/L. Proses aerasi menghasilkan air dengan turbidity 15,21 NTU. Proses aerasi juga dilakukan dengan didiamkan selama semalam sehingga tingkat kekeruhan air jauh lebih kecil, yaitu 5,23 NTU, COD 46,1; TSS $19 \mathrm{mg} / \mathrm{L}$. Percobaan ini menunjukkan bahwa proses aerasi lebih optimal apabila setelah proses aerasi air yang diolah didiamkan terlebih dahulu.

\subsection{Pretreatment dengan Media Filtrasi Pasir Aktif dan Karbon Aktif sebelum Membran Bioreaktor}

Pasir aktif memiliki karakteristik sebagai pengikat unsur besi (Fe), mangan (Mn), serta sulfida dalam air. Saat air melewati pasir aktif, padatan, mikororganisme dan logam berat dapat dipisahkan. Penggunaan pasir aktif juga dapat mencegah fouling(penyumbatan). Sementara karbon aktif bisa terbuat dari berbagai macam bahan baku. Karbon aktif biasanya digunakan dalam proses filtrasi untuk menyerap senyawa organik, bau, dan rasa yang hasilnya tergantung kualitas dari karbon aktif tersebut. Bahkan saat menggunakan karbon aktif untuk menyerap senyawa organik tidak diperlukan proses pengolahan air sebelumnya.

Pada penelitian ini, pengolahan air setelah proses aerasi dilakukan melalui tiga rute. Yang pertama, air dilewatkan langsung tanpa melewati media filtrasi. Kualitas air saat air langsung dilewatkan membran bioreaktor tanpa media filtrasi masih memiliki tingkat kekeruhan 0,33 NTU dengan nilai COD 35,7. Sementara tingkat efisiensi penurunan TDS dan TSS adalah $91,05 \%$ dan $68 \%$. Percobaan menggunakan media filtrasi pasir aktif menunjukkan hasil yang lebih efektif dibandingkan media filtrasi karbon aktif. Hal ini dikarenakan pasir aktif memiliki karakteristik untuk memisahkan padatan dan mikroorganisme serta dapat mencegah fouling. Kualitas air hasil laboratorium menunjukkan bahwa proses menggunakan media pasir aktif memiliki tingkat kekeruhan 0 NTU dengan nilai COD 7,1; serta efisiensi penurunan TDS dan TSS adalah $91,85 \%$ dan $76 \%$. Sementara pada saat menggunakan media karbon aktif, angka kekeruhan masih 0,27 NTU dengan nilai COD 10,5. Efisiensi penurunan TDS dan TSS $90,97 \%$ dan $66,67 \%$.
Tabel 1. Data Percobaan

\begin{tabular}{lrrrrrr}
\hline & \multicolumn{2}{c}{$\begin{array}{c}\text { tanpa media } \\
\text { filtrasi }\end{array}$} & \multicolumn{2}{c}{ pasir aktif } & \multicolumn{2}{c}{ karbon aktif } \\
\cline { 2 - 7 } Parameter & $\begin{array}{c}\text { konsen } \\
\text { trasi } \\
(\mathrm{mg} / \mathrm{L})\end{array}$ & $\begin{array}{c}\text { eff } \\
(\%)\end{array}$ & $\begin{array}{c}\text { konsen } \\
\text { trasi } \\
(\mathrm{mg} / \mathrm{L})\end{array}$ & $\begin{array}{c}\text { eff } \\
(\%)\end{array}$ & $\begin{array}{c}\text { konsen- } \\
\text { trasi } \\
(\mathrm{mg} / \mathrm{L})\end{array}$ & eff $(\%)$ \\
\hline kekeruhan & 0,33 & 98,13 & 0,00 & 100 & 0,27 & 98,91 \\
COD & 47,42 & 47,42 & 7,10 & 88,13 & 10,50 & 77,22 \\
TSS & 8,00 & 33,33 & 6,00 & 76,00 & 4,00 & 66,67 \\
TDS & 168,00 & 91,05 & 157,00 & 91,85 & 170,00 & 91,23 \\
\hline
\end{tabular}

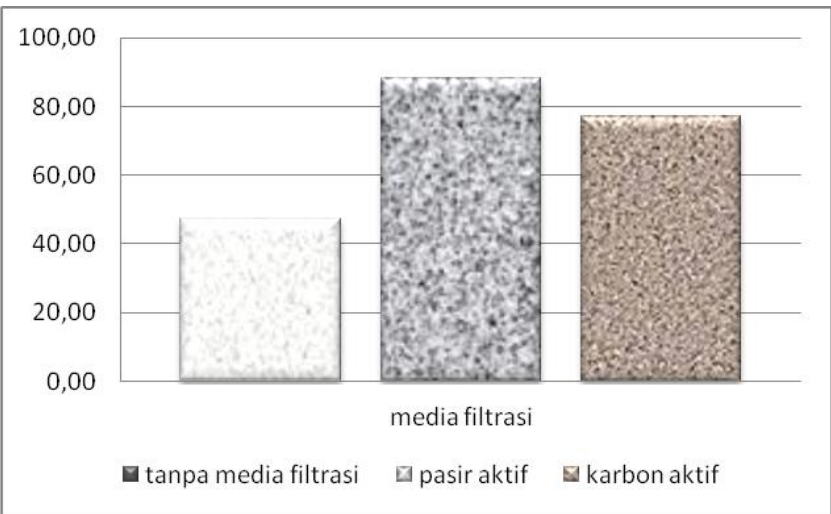

Gambar 6. Efektivitas penurunan $\operatorname{COD}(\%)$

Gambar 6 menunjukkan bahwa penggunaan media pasir aktif sebagai media filtrasi sebelum air dilewatkan dalam membran bioreaktor memiliki efektivitas penurunan COD yang paling baik. COD (Chemical Oxygen Demand) adalah kebutuhan oksigen yang dibutuhkan untuk mengoksidasi bahan organik secara kimiawi. Nilai COD saat air terproduksi tidak melewati proses filtrasi sebelum masuk membran reaktor masih sangat tinggi, yaitu 35,7 ppm dari 67,9 ppm pada saat air keluar proses aerasi. Pada saat air terproduksi dilewatkan dalam media filtrasi pasir aktif, nilai COD 7,1 ppm atau memiliki persentase penurunan $88,13 \%$. Sedangkan untuk media filtrasi karbon aktif, nilai COD lebih tinggi yaitu $10,5 \mathrm{ppm}$ atau persentase penurunan $77,22 \%$.

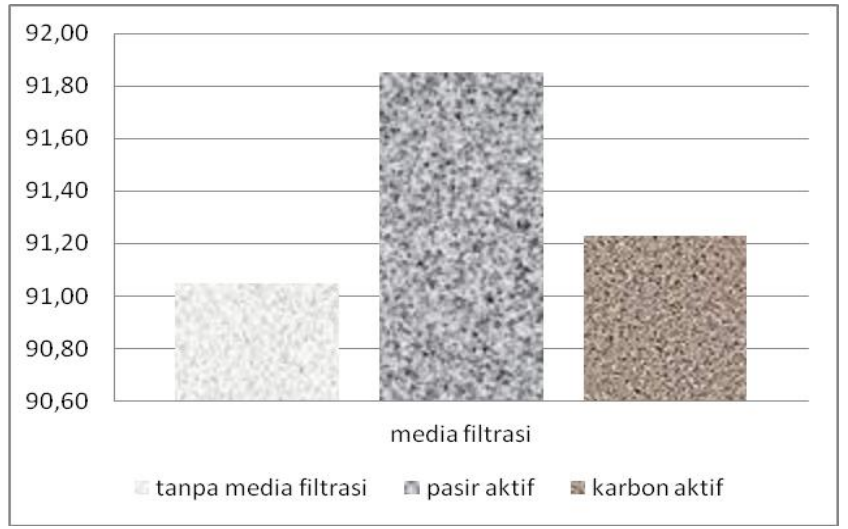

Gambar 7.Efektivitas penurunan TDS (\%) 
Total dissolved Solids (TDS) adalah jumlah padatan terlarut dalam air. TDS merupakan indikator jumlah partikel dalam air, baik senyawa organik maupun nonorganik. Air terproduksi hasil proses aerasi memiliki nilai TDS yang masih sangat tinggi, yaitu 1938 ppm. Untuk mencegah terjadinya fouling pada membran bioreaktor, air terproduksi dilewatkan dalam media filtrasi pasir aktif dan karbon aktif. Saat menggunakan media pasir aktif, nilai TDS 157 ppm sementara saat menggunakan media filtrasi karbon aktif nilai TDS lebih tinggi yaitu 170 ppm. Hal ini menunjukkan bahwa pasir aktif memiliki karakteristik bisa menahan padatan terlarut seperti logam berat dan mikiroorganisme lebih baik daripada karbon aktif. Untuk pengolahan air bersih, karbon aktif digunakan untuk menyerap senyawa organik dan dapat menghilangkan bau dan rasa. Dari data penurunan nilai TDS terlihat pada Gambar 7, dimana penurunan TDS terbaik adalah menggunakan media pasir aktif dengan efektivitas $91,85 \%$

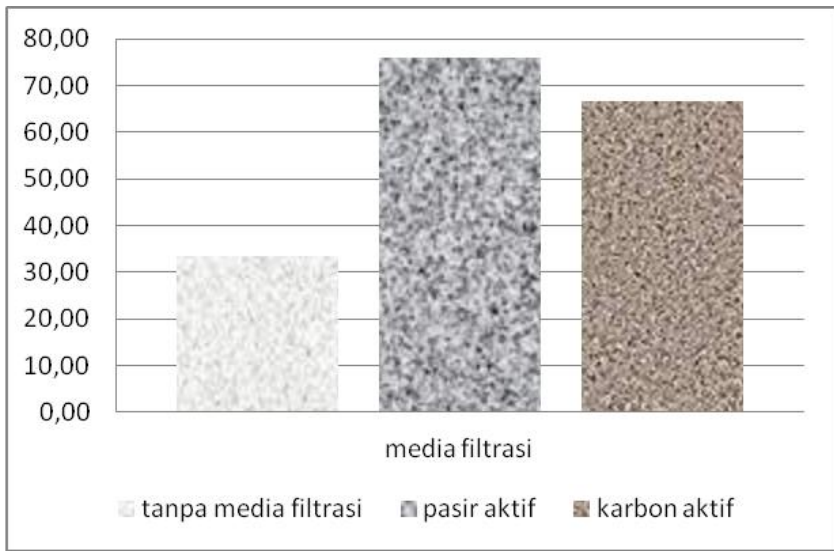

Gambar 8. Efektivitas penurunan TSS (\%)

Total Suspended Solids (TSS) adalah jumlah padatan yang tersuspensi dalam air. Contoh padatan tersuspensi adalah logam oksida, lumpur, dan tanah liat yang tidak terlarut dalam air. TSS bisa berkurang saat melewati proses flokulasi dan sedimentasi, yaitu pre-treatment sebelum masuk membran bioreaktor. Besarnya TSS saat air terproduksi akan masuk membran adalah $12 \mathrm{mg} / \mathrm{L}$. Sedangkan setelah melewati membran biorektor tanpa media filtrasi, dengan media pasir aktif, dan dengan media karbon aktif masing-masing $8 \mathrm{mg} / \mathrm{L}, 6 \mathrm{mg} / \mathrm{L}$, dan $4 \mathrm{mg} / \mathrm{L}$. Dari data tersebut terlihat bahwa penggunaan membran bioreaktor tidak berpengaruh secara signifikan terhadap turunnya nilai TSS. Hal ini karena padatan tersuspensi secara fisika bisa dipisahkan dengan cara digumpalkan dan kemudian diendapkan sebelum air melewati membran bioreaktor. Gambar 8 menunjukan bahwa media pasir aktif dapat menurunkan nilai TSS paling besar, yaitu $76 \%$.

Turbidity menunjukkan tingkat kekeruhan air yang memiliki satuan NTU (Nephelometric Turbidity Unit). Sebelum air terproduksi melewati membran, nilai kekeruhan yaitu 23,03 NTU. Saat air terproduksi dilewatkan membran biorekator tanpa menggunakan media filtrasi, nilai kekeruhan masih 0,33 NTU. Sementara pada saat menggunakan media filtrasi karbon aktif sebelum membran, nilai kekeruhan berkurang menjadi 0,27 NTU. Nilai kekeruhan mencapai 0 NTU saat menggunakan media filtrasi pasir aktif. Data tersebut terlihat pada gambar 89 di mana persentase penurunan turbidity saat menggunakan media pasir aktif mencapai $100 \%$.

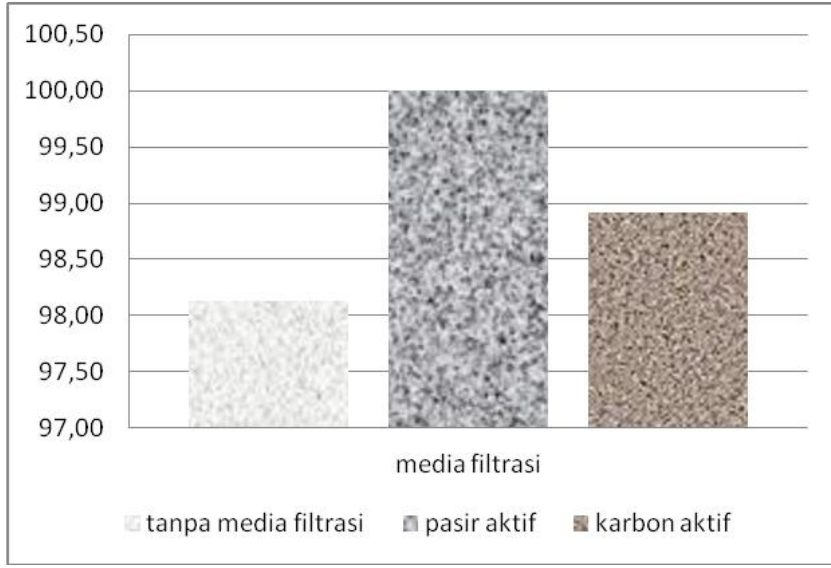

Gambar 9. Efektivitas penurunan Turbidity / kekeruhan $(\%)$

Dari hasil penelitian diperoleh hasil optimum pada pengolahan air menggunakan media filtrasi pasir aktif. Parameter yang digunakan untuk mengetahui kualitas air adalah COD, TDS, TSS, dan kekeruhan. Pada setiap parameter, pengolahan air terproduksi menggunakan membran dengan media filtrasi pasir aktif memiliki efektivitas yang paling besar.

Tabel 2. Penuruan Kekeruhan Menggunakan Pengolahan Sedimentasi dan Filtrasi Pasir Aktif

\begin{tabular}{cc}
\hline Input (NTU) & Output (NTU) \\
\hline 40.37 & 1.42 \\
19.43 & 4.02 \\
31.71 & 4.98 \\
100 & 4.12 \\
44.12 & 5.68 \\
53.67 & 25.01 \\
56 & 22.78 \\
\hline
\end{tabular}

Penelitian pengolahan air terproduksi juga telah dilakukan oleh Yogafanny (2018). Pengolahan dilakukan dengan melewatkan air dengan bahan baku (air limbah) yang sama, pada pasir aktif pada proses tahap akhir. Analisis dilakukan sampai hari ke-7 dan hasil analisis menunjukkan performa menurun dari hari pertama samapai hari ke-7. Pada hari pertama, kualitas air terproduksi memiliki kekeruhan yang kecil yaitu 1,42 NTU. Namun pada pengambilan data selanjutnya, performa menurun karena disebabkan oleh pasir aktif yang sudah jenuh. 
Dari hasil penelitian tersebut, dapat disimpulkan bahwa teknologi membran dapat mengolah air terproduksi dengan baik, bahkan sampai kekeruhan 0 NTU untuk pre-treatment menggunakan pasir aktif. Adanya pretreatment digunakan untuk mengurangi beban membran karena air terlebih dahulu sudah mengalami penurunan tingkat kekeruhan dan memperlambat proses fouling sehingga umur membran lebih lama.

Sartor et.al., (2008) juga memperlihatkan bahwa penggunaan membran bioreaktor sangat memungkinkan untuk kondisi di negara berkembang. Hasil penelitian menunjukkan bahwa teknologi membran bioreaktor merupakan salah satu proses penting untuk instalasi pengolahan limbah yang terdesentralisasi. Pengolahan menggunakan membran biorekator mampu menurunkan zat organik dengan pengolahan air limbah secara biologis dan mampu menurunkan padatan tersuspensi dalam satu langkah. Keunggulan membran bioreaktor menurut Sarto et.al adalah desain yang praktis, tidak ada kelebihan lumpur dan kualitas air yang baik.

John Hoslett et.al., pada tahun 2018 ini juga telah melakukan penelitian pengolahan air menggunakan membran dengan proses filtrasi sebelum air dilewatkan ke membran. Media filtrasi dilakukan untuk mencegah fouling pada membran. Bahan isian yang digunakan adalah Slow Sand Fultration (SSF), Rapid Sand Filtration (RPS), dan Granular Activated Carbon (GAC). SSF dapat secara sederhana dan mudah dioperasikan untuk menghilangkan zat padat, mikroorganisme dan logam berat. Namun demikian, perluasan area yang besar per satuan volume air yang diolah diperlukan. Di daerah perkotaan di mana ruang yang tersedia terbatas, RSF dapat digunakan untuk treatment sebelum dan sesudah untuk mencegah fouling. Dengan cara melapisi filter pasir dengan zat aditif berbasis logam (misalnya $\mathrm{Fe}$ atau $\mathrm{Mn}$ ) adalah proses yang relatif mudah yang dapat meningkatkan potensi adsorpsi secara signifikan. Oleh karena itu, penyaringan pasir direkomen-dasikan untuk digunakan di negara berkembang. Menurut John Hoslett, GAC umumnya digunakan sebagai post filtration untuk untuk menyerap senyawa organik, rasa, bau dengan hasil tergantung kualitas karbon. GAC mengadsorpsi senyawa organik yang tidak disaring pada tahap sebelumnya. Dengan dikombinasikan dengan metode lain (misalnya MF dan SSF), GAC merupakan cara yang hemat biaya untuk menghasilkan air minum berkualitas yang dapat diterima di negara-negara yang kurang berkembang.

\section{Kesimpulan}

Penelitian menggunakan membran bioreaktor memerlukan proses pre-treatment menggunakan bahan isian karena jika tidak, membran akan cepat jenuh dalam menahan padatan terlarut. Bahan isian yang paling efektif untuk dan menghasilkan kualitas air terbaik adalah menggunakan media pasir aktif. Jika tanpa proses pre-treatment masih memiliki tingkat kekeruhan 0,33 NTU dengan nilai COD 35,7. Sementara tingkat efisiensi penurunan TDS dan TSS adalah $91,05 \%$ dan $68 \%$. Sedangkan jika dilakukan proses pretreatment menggunakan media filtrasi pasir aktif kualitas air memiliki tingkat kekeruhan 0 NTU dengan nilai COD 7,1; serta efisiensi penurunan TDS dan TSS adalah $91,85 \%$ dan $76 \%$. Sementara pada saat menggunakan media karbon aktif, angka kekeruhan masih 0,27 NTU dengan nilai COD 10,5. Efisiensi penurunan TDS dan TSS $90,97 \%$ dan $66,67 \%$.

\section{Ucapan Terimakasih}

Kami mengucapkan terimakasih kepada Lembaga Penelitian dan Pengabdian kepada Masyarakat (LPPM) karena Penelitian ini didukung secara finansial oleh LPPM Universitas Pembangunan Nasional (UPN) "Veteran" Yogyakarta, Indonesia melalui Dana Hibah 2018. Kami juga berterima kasih kepada rekan-rekan dan asisten mahasiswa dari Jurusan Teknik Lingkungan UPN Veteran Yogyakarta yang mendukung penelitian ini. Akhir kata, kami mendedikasikan penelitian ini kepada Ketua Komunitas Petroleum Geoheritage Wonocolo, Bapak Suyitno (Pak Yossi) yang memberikan keahlian dan dukungan tanpa syarat selama kerja lapangan di Wonocolo. Dia telah meninggal pada bulan Agustus 2018 dan makalah ini juga untuk menghafal kebaikannya.

\section{Daftar Pustaka}

Anggraeni \& Kurniasari. 2016. Penggunaan Membran Bioreaktor (MBR) Pasa Activated Sludge dalam Pengolahan Limbah Cair Industri. Jurusan Teknik Kimia. ITS

Akhsani. 2016. Aplikasi Membran Bioreaktor dalam Pengolahan Air Limbah Indusrti. Departemen Teknik Kimia, Institut Teknologi Bandung

Hartuno, Udiantoro, \& Agustina. 2014. Desain Water Treatment Menggunakan Karbon Aktif dari Cangkang Kelapa Sawit pada Proses Pengolahan Air Bersih di Sungai Martapura. Jurnal Ziraa'ah. Vol 39 Nomor 3

Hoslett, Massara, Mamalis, Ahmad, Boogaert. 2018. Surface Water Filtration Using Granular Media and Membrane. Science of Total Environment. 1268-1282

Ivory, D. 2015. Prospek Pemanfaatan Air Terproduksi. Departemen Teknik Kimia. Institut Teknolgi Bandung. 01-09

Kristiati, M. Th., 2010. Minyak Bumi: Eksplorasi, Eksploitasi, dan Produksi, PT. Citra Aji Pratama, Yogyakarta

Mulder, M. 1996. Basic Principle of Membran Technology. Kluwer Academic Publisher. Netherlands

Notodarmojo, Mayasanthy, \& Zulkarnain. 2004. Pengolahan Limbah Cair Emulsi Minyak dengan Proses Membran Ultrafiltrasi Dua-Tahap Aliran Cross-Flow. PROC ITB Sains \& Tek, Vol 36. A No1, 45-62

Sartor, M., Kaschek, M., \& Mavrov, V. 2008. Feasability Study for evaluating the client application of membrane bioreactor (MBR) Technology for Decentralised 
Municipal Wastewater Treatment in Vietnam. Science Direct. Desalination 224(172-177)

Wenten,I.G. 2004. Bioreaktor Membran untuk Pengolahan Limbah. Departemen Teknik Kimia. Intitut Teknologi Bandung

Wenten, I.G. 2014. Desain Proses Berbasis Membran. Departemen Teknik Kimia. Insitut Teknologi Bandung

Wenten, I.G., 2016. Ultrafiltration in Water Treatment and Its Evaluation as Pretreatment for Reverse Osmosis System. Departemen Teknik Kimia. Intitut Teknologi Bandung. 3-4

Yogafanny E., MTh. Kristiati ES., A. Utami, W.W.Nandari, 2018, Pengelolaan Lingkungan Industri Minyak Gas dan Panas Bumi , LPPM UPN "Veteran”, Yogyakarta 